\title{
Two decades since the fetal insulin hypothesis: what have we learned from genetics?
}

\author{
Alice E. Hughes ${ }^{1}$ (D) $\cdot$ Andrew T. Hattersley ${ }^{1}$ (D) $\cdot$ Sarah E. Flanagan $^{1}$ (D) $\cdot$ Rachel M. Freathy $^{1}$ (D)
}

Received: 29 September 2020 / Accepted: 25 November 2020 / Published online: 11 February 2021

(C) The Author(s) 2021

\begin{abstract}
In 1998 the fetal insulin hypothesis proposed that lower birthweight and adult-onset type 2 diabetes are two phenotypes of the same genotype. Since then, advances in research investigating the role of genetics affecting insulin secretion and action have furthered knowledge of fetal insulin-mediated growth and the biology of type 2 diabetes. In this review, we discuss the historical research context from which the fetal insulin hypothesis originated and consider the position of the hypothesis in light of recent evidence. In summary, there is now ample evidence to support the idea that variants of certain genes which result in impaired pancreatic beta cell function and reduced insulin secretion contribute to both lower birthweight and higher type 2 diabetes risk in later life when inherited by the fetus. There is also evidence to support genetic links between type 2 diabetes secondary to reduced insulin action and lower birthweight but this applies only to loci implicated in body fat distribution and not those influencing insulin resistance via obesity or lipid metabolism by the liver. Finally, we also consider how advances in genetics are being used to explore alternative hypotheses, namely the role of the maternal intrauterine environment, in the relationship between lower birthweight and adult cardiometabolic disease.
\end{abstract}

Keywords Birthweight $\cdot$ Fetal growth restriction $\cdot$ Fetal insulin $\cdot$ Genome-wide association studies $\cdot$ Mendelian randomisation $\cdot$ Neonatal diabetes $\cdot$ Pregnancy $\cdot$ Review $\cdot$ Type 2 diabetes

Abbreviations
$\begin{array}{ll}\text { DOHaD } & \text { Developmental Origins of Health and Disease } \\ \text { GWAS } & \text { Genome-wide association studies } \\ \text { SBP } & \text { Systolic BP } \\ \text { SDS } & \text { SD score }\end{array}$

\section{Introduction}

Lower birthweight is associated with a higher risk of adult cardiometabolic disease, including type 2 diabetes [1]. This relationship was first observed in a study from 1991 linking birthweight records to results of glucose tolerance tests performed in adult men [2], and multiple epidemiological studies have since confirmed this association [3]. The 'thrifty phenotype' hypothesis was put forward as an explanation in

Rachel M. Freathy

r.freathy@exeter.ac.uk

1 Institute of Biomedical and Clinical Science, University of Exeter Medical School, Exeter, UK
1992, suggesting that maternal malnutrition led to poor fetal growth, with adaptation to a nutritionally depleted intrauterine environment resulting in abnormal pancreatic beta cell function and reduced capacity to secrete insulin extending into adult life [4]. The thrifty phenotype hypothesis has since expanded to include preconceptual, periconceptual and other intrauterine exposures and postnatal outcomes, and is now known as the Developmental Origins of Health and Disease (DOHaD) hypothesis [5].

An alternative explanation (the fetal insulin hypothesis) was put forward in 1998, proposing that lower birthweight and adult-onset type 2 diabetes are two phenotypes of the same genotype (Fig. 1) [6, 7]. Jørgen Pedersen identified fetal insulin as a key intrauterine growth factor in 1952 [8] and this, together with the observation that monogenic diseases affecting insulin secretion and action were accompanied by lower birthweight, formed the premise of the fetal insulin hypothesis. It proposed that insulin secretion and resistance, genetically determined and present from conception, also affect intrauterine growth and explain the relationship between lower birthweight and adult-onset type 2 diabetes observed in epidemiological studies [1-3]. 
Fig. 1 Principles of the fetal insulin hypothesis compared with the thrifty phenotype hypothesis. This figure is available as part of a downloadable slideset

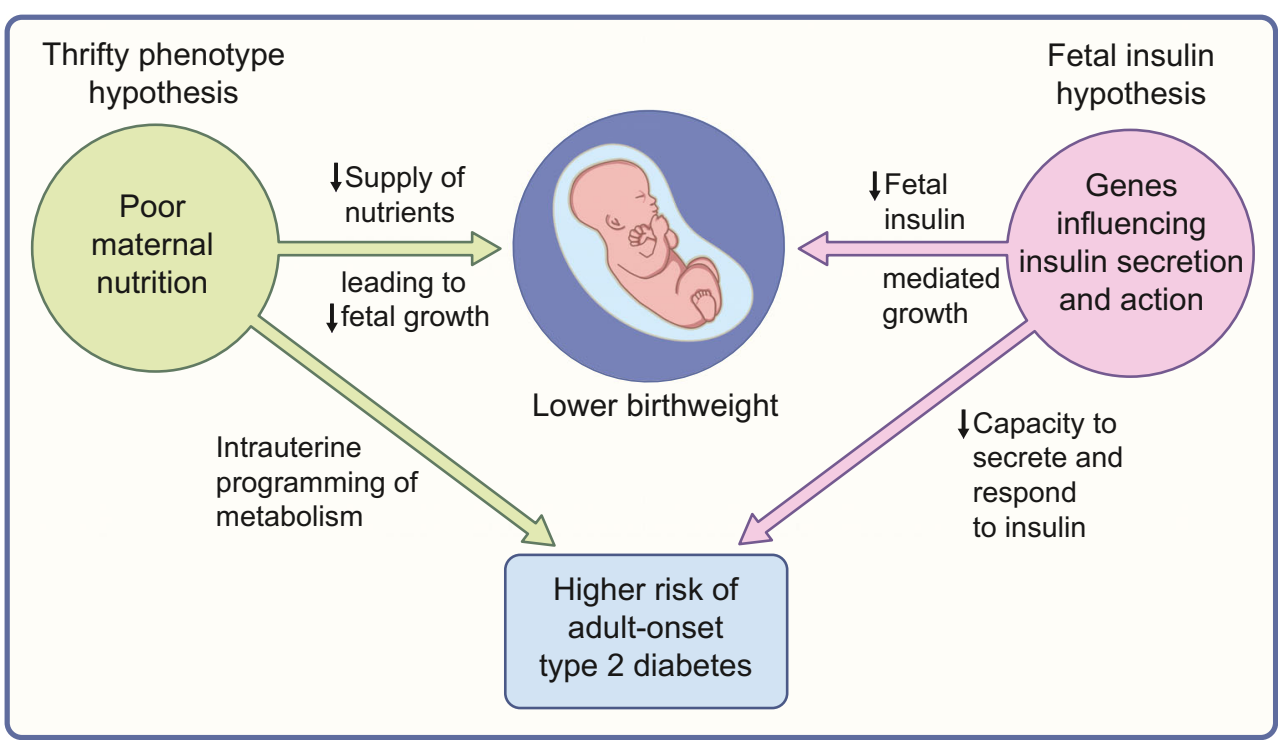

In the two decades since the fetal insulin hypothesis was founded, advances in research encompassing the genetics of type 2 diabetes and birthweight have made it possible to test the hypothesis and answer important questions about the relationship between fetal growth and development of type 2 diabetes in later life. In this review, we evaluate the evidence for and against the fetal insulin hypothesis, considering recent evidence from genetic and epidemiological studies. We also consider how genetics could be utilised to explore the complex relationships between the intrauterine environment, fetal genotype and adult-onset type 2 diabetes. The scope of the review does not encompass evaluation of the position of the $\mathrm{DOHaD}$ hypothesis in relation to type 2 diabetes risk, as this has been considered in detail in another recent review [9].

\section{The fetal insulin hypothesis from the perspective of monogenic research}

\section{The role of fetal genotype in determining insulin- mediated growth in utero: studies in families affected by GCK-MODY}

A study of birthweights from pregnancies affected by MODY due to a heterozygous mutation in the glucokinase gene $(G C K)$ [6] provided important insights into how the fetal genotype determines insulin-mediated growth in utero. These mutations result in reduced sensing of glucose by the pancreatic beta cell, so individuals with $G C K$-MODY regulate glucose at a higher setpoint (fasting plasma glucose $5.5-8 \mathrm{mmol} / \mathrm{l}[10]$ ) and have stable, mild hyperglycaemia throughout life [11]. An analysis of birthweights in 23 families with $G C K$-MODY found that where the mother had $G C K$-MODY and her fetus did not, birthweight was approximately $600 \mathrm{~g}$ higher than average due to higher fetal insulin secretion in response to maternal hyperglycaemia. However, when the fetus had inherited the $G C K$ mutation from their mother, birthweight was no different from average because in such pregnancies glucose is sensed by both mother and fetus at the same level and a normal amount of insulin is secreted. In contrast, where the mother did not have GCK-MODY and the fetus had inherited a mutation in $G C K$ from the father, birthweight was reduced by approximately $500 \mathrm{~g}$ (Table 1 ). In this case, maternal glucose crossing the placenta is sensed at a higher threshold by the fetus, resulting in less insulin secretion. This work contributed important knowledge to the relationship between maternal blood glucose levels and fetal genotype in regulating intrauterine growth, prompting the proposal of the fetal insulin hypothesis [7].

Studying the genetics of $G C K$-MODY pregnancies to gain knowledge of birthweight has been clinically important as it has informed obstetric care. Historically, these at-risk pregnancies were monitored with serial ultrasound scans and the fetus was assumed not to have inherited the maternal mutation if there was evidence of fetal overgrowth (abdominal circumference $>75$ th percentile for gestational age). In this case, treatment of maternal hyperglycaemia was trialled, followed by planned delivery at 38 weeks gestation to mitigate the intra- and postpartum risks of having a large-for-gestational-age (LGA) baby. More recently, non-invasive prenatal diagnostic testing of cell-free fetal DNA in maternal blood has become available [12] and has the potential to prevent unnecessary treatment of maternal hyperglycaemia in fetuses who have inherited a $G C K$ mutation.

\section{Single-gene mutations that result in reduced insulin secretion typically reduce birthweight}

The discovery that neonatal diabetes is commonly caused by mutations in single genes affecting insulin secretion has lent 
Table 1 Birthweight in monogenic diseases associated with reduced insulin secretion and action

\begin{tabular}{|c|c|c|c|c|}
\hline Gene & Disease & $\begin{array}{l}\text { Effect on birthweight } \\
\text { at term gestation }\end{array}$ & $\begin{array}{l}\text { In support of fetal } \\
\text { insulin hypothesis? }\end{array}$ & References \\
\hline \multicolumn{5}{|l|}{ Reduced insulin secretion } \\
\hline$G C K$ & MODY & $\downarrow \sim 500 \mathrm{~g}$ & $\checkmark$ & {$[6]$} \\
\hline HNF1A & MODY & $\leftrightarrow$ Normal & $x$ & {$[29]$} \\
\hline$H N F 4 A$ & MODY & $\uparrow \sim 800 \mathrm{~g}$ & $x$ & {$[29]$} \\
\hline$H N F 1 B$ & MODY & $\downarrow \sim 800 \mathrm{~g}$ & $\checkmark$ & [77] \\
\hline ABCC8, KCNJ11 & Neonatal diabetes & $\downarrow \sim 800 \mathrm{~g}$ & $\checkmark$ & {$[13-16]$} \\
\hline \multicolumn{5}{|l|}{ Absent insulin secretion } \\
\hline INS & Neonatal diabetes & $\downarrow \sim 1500 \mathrm{~g}$ & $\checkmark$ & {$[17]$} \\
\hline CNOT1, GATA4, GATA6, PDX1, PTF1A & Pancreatic agenesis & $\downarrow \sim 1500 \mathrm{~g}$ & $\checkmark$ & [18-23] \\
\hline \multicolumn{5}{|l|}{ Insulin resistance } \\
\hline INSR & Congenital insulin resistance & $\downarrow \sim 1500 \mathrm{~g}$ & $\checkmark$ & {$[33-35]$} \\
\hline AGPAT2, BSCL2, CAV1 & Congenital generalised lipodystrophy & $\leftrightarrow$ Normal & $x$ & {$[37,78-80]$} \\
\hline$L M N A, P P A R G$, PLIN1 & Familial partial lipodystrophy & $\leftrightarrow$ Normal & $\times$ & {$[38-42]$} \\
\hline
\end{tabular}

further support to the fetal insulin hypothesis (Table 1) [6, 13-23]. These cases are rare and represent a severe phenotype but the principle that genetics determines both fetal growth and postnatal insulin secretion is supported by the observation that infants with neonatal diabetes have very low birthweights (median SD score (SDS) for sex and gestational age -1.7 [24]). Furthermore, the severity of fetal growth restriction depends on the amount of fetal insulin secretion, as infants with complete absence of fetal insulin secretion due to loss-offunction mutations in the insulin gene or pancreatic agenesis are half of normal birthweight by term gestation (median SDS for sex and gestational age $<-3.0$, unpublished data from A. Hughes et al). This is in contrast to other animal species, where absent fetal insulin secretion reduces birthweight to a much lesser extent than in humans [25]. Therefore, human birthweight is a bioassay of inherent insulin secretory capacity, and monogenic disorders of insulin secretion provide unique insights into the genetic link between lower birthweight and diabetes resulting from reduced insulin secretion.

\section{Birthweights in HNF4A-MODY and HNF1A-MODY are not consistent with the fetal insulin hypothesis}

Not all instances of monogenic diabetes secondary to reduced insulin secretion are associated with lower birthweight. Heterozygous mutations in the genes encoding the transcription factors hepatic nuclear factor- $4 \alpha$ and $-1 \alpha$ (HNF4A and $H N F 1 A$, respectively) result in reduced insulin secretion [26, 27] and mutation carriers develop diabetes in childhood or early adulthood [28]. The fetal insulin hypothesis would predict that affected individuals have a low birthweight, yet individuals with HNF1A-MODY have normal birthweights and inheritance of $H N F 4 A-M O D Y$ is associated with fetal and neonatal hyperinsulinism and macrosomia (Table 1) [29]. It has been proposed that fetal hyperinsulinism causes accelerated postnatal pancreatic beta cell apoptosis, which subsequently predisposes to early-onset diabetes [30]. However, it has recently been found that higher birthweight is associated with reduced penetrance of $H N F 4 A-M O D Y$ (unpublished data from J. Locke and K. Patel). Therefore, higher birthweight in HNF4A-MODY is likely to represent a greater inherent capacity to secrete insulin, and differential expression of HNF4A isoforms in the fetus and in later life $[31,32]$ may provide an alternative explanation for these contrasting effects of $H N F 4 A$ mutations.

\section{Monogenic diseases resulting in severe insulin resistance have heterogeneous effects on birthweight}

The relationship between birthweight and monogenic diabetes secondary to impaired insulin action is unclear (Table 1). Consistent with the fetal insulin hypothesis, infants with severe congenital insulin resistance secondary to loss-offunction mutations in the insulin receptor gene, INSR, have very low birthweights [33-35]. Single-gene mutations resulting in either congenital generalised or familial partial lipodystrophy are characterised by peripheral insulin resistance due to an absence of subcutaneous adipose tissue, and affected individuals typically develop diabetes in adolescence [36]. However, birthweights of infants with congenital generalised lipodystrophy have been reported to be normal [37] and though there are reports of low birthweight in familial partial lipodystrophy [38, 39], this has not been widely reported as a typical clinical feature in the literature [40-42]. 


\section{The fetal insulin hypothesis from the perspective of epidemiological research}

\section{Paternal type 2 diabetes is associated with lower offspring birthweight but is not clearly related to heritable insulin resistance}

Observational studies of paternal diabetes status and offspring birthweight have provided evidence for a shared genetic predisposition to lower birthweight and type 2 diabetes [43, 44]. The study of paternal diabetes is important, since maternal diabetes leads to higher birthweight [45] and masks the effect of fetal genes predisposing to diabetes inherited from the father. This was clearly shown by a study of 236,030 participants (UK Biobank study) wherein paternal diabetes was associated with a $45 \mathrm{~g}$ lower birthweight compared with birthweights of infants who had no parent with diabetes. In contrast, birthweight in offspring of parents who both had diabetes was not different from birthweight of infants for whom neither parent had diabetes(Fig. 2) [43].

The fetal insulin hypothesis proposed a possible role for heritable insulin resistance, and there has been evidence for a relationship between low birthweight and higher levels of paternal insulin resistance in case-control $(n=119)$ [46] and cross-sectional $(n=2788)$ [47] studies. However, paternal insulin resistance was not independently associated with offspring birthweight in a birth-cohort study of 986 UK parentoffspring trios [48], and there was a positive correlation between paternal HOMA-IR and umbilical cord insulin levels in 644 fathers and babies [49]. Together, this suggests that in utero there may in fact be a compensatory rise in insulin levels in the face of insulin resistance to maintain fetal growth.

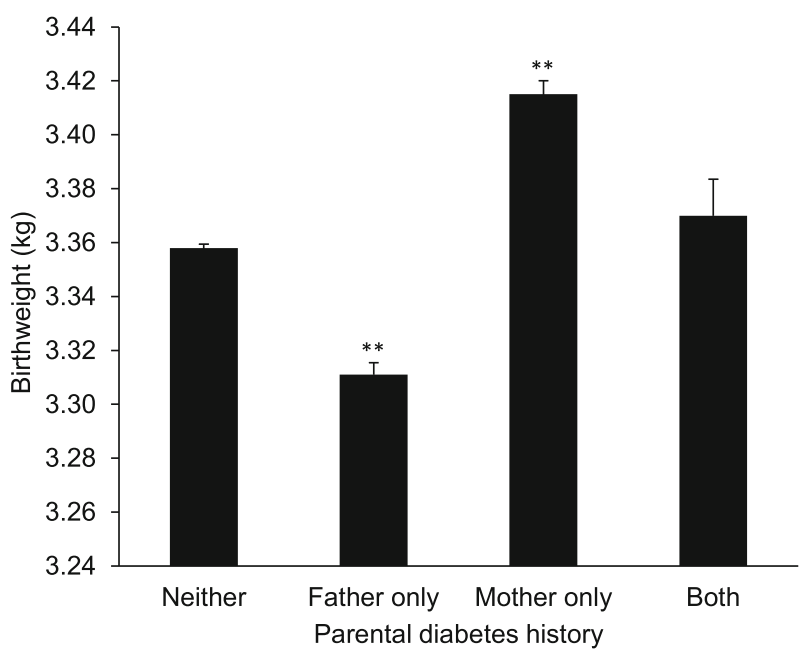

Fig. 2 Birthweight according to parental diabetes status in the UK Biobank study [43]. $* * p<0.001$ vs birthweight where neither parent was reported to have diabetes. Figure adapted from Tyrell et al [43] under the terms of the Creative Commons Attribution 3.0 Unported License. This figure is available as part of a downloadable slideset
The fetal insulin hypothesis from the perspective of polygenic research

\section{Type 2 diabetes risk loci are associated with lower birthweight}

The first genome-wide association studies (GWAS) transformed the landscape of research into the genetics of type 2 diabetes [50-52] and allowed us to test the fetal insulin hypothesis. Initially, variants at type 2 diabetes risk loci affecting insulin secretion were tested for their association with birthweight and it was found that fetal risk alleles at the CDKAL1 and HHEX-IDE loci were associated with a lower birthweight $[53,54]$. The effect was also important; the reduction in birthweight in a fetus carrying four risk alleles was equivalent to that seen in a fetus whose mother smoked three cigarettes per day in the third trimester of pregnancy.

The first GWAS for birthweight shortly followed [55] and one of the first variants identified was at the known type 2 diabetes risk locus in $A D C Y 5$, which plays a key role in coupling glucose to insulin secretion from the pancreatic beta cell [56]. Since then, successively larger GWAS of birthweight, with the latest including data on $>400,000$ individuals, have identified a total of 190 loci associated with birthweight [57-59]. Using a recently developed method $[59,60]$, the statistical power from these large samples could then be harnessed to estimate the independent maternal and fetal effects at each locus. To date, 11 variants with fetal effects both on birthweight and on type 2 diabetes risk have been identified (Table 2).

\section{There is heterogeneity in the relationship between birthweight and type 2 diabetes risk loci}

Type 2 diabetes risk alleles associated with pancreatic beta cell function The strongest associations between type 2 diabetes risk alleles and lower birthweight are at loci that primarily affect pancreatic beta cell function (e.g. ADCY5 and $C D K A L 1$; Fig. 3). However, not all risk alleles at beta cell loci are associated with lower birthweight. For example, the fetal risk allele at $T C F 7 L 2$, which has a relatively large effect on type 2 diabetes risk, has no effect on birthweight, and the fetal risk allele at the ANK1 locus is associated with a higher birthweight [59] despite its role in regulating NKX6-3 [61], a vital transcription factor involved in pancreatic beta cell development [62]. These emerging patterns of association are consistent with the heterogeneous birthweight effects of monogenic causes of diabetes secondary to reduced insulin secretion and suggest that different susceptibility loci exert their effects on beta cell function at different stages in the life course. 
Table 2 Fetal risk loci associated with birthweight and type 2 diabetes

\begin{tabular}{lll}
\hline $\begin{array}{l}\text { Birthweight and type } \\
2 \text { diabetes risk locus }\end{array}$ & $\begin{array}{l}\text { Effect of fetal type 2 diabetes } \\
\text { risk-raising allele on } \\
\text { birthweight }(z \text { score })\end{array}$ & $\begin{array}{l}\text { Likely biology underlying type } \\
\text { 2 diabetes risk }\end{array}$ \\
\hline IRS1 & -0.02 & Higher insulin resistance [81, 82] \\
$A D C Y 5$ & -0.06 & Reduced insulin secretion [81, 82] \\
$C D K A L 1$ & -0.05 & Reduced insulin secretion [81, 82] \\
ANK1 & +0.03 & Reduced insulin secretion [81, 82] \\
GPSM1 & -0.02 & Not known \\
$H H E X / I D E$ & -0.04 & Reduced insulin secretion [81, 82] \\
$P L E K H A 1$ & -0.02 & Not known \\
$I N S-I G F 2$ & -0.03 & Not known \\
$K C N Q 1$ & -0.02 & Reduced insulin secretion [81, 82] \\
$C C N D 2$ & -0.01 & Reduced insulin secretion [81, 82] \\
$H M G A 2$ & -0.04 & Reduced insulin secretion [83] \\
\hline
\end{tabular}

Birthweight SNPs [59] at these loci are in linkage disequilibrium $\left(R^{2}>0.3\right)$ with a primary or secondary signal type 2 diabetes SNP [61]. A 1 SD change in birthweight is equivalent to $\sim 450 \mathrm{~g}$
Type 2 diabetes risk alleles associated with insulin resistance, obesity or liver lipid metabolism Certain type 2 diabetes risk alleles associated with insulin resistance secondary to a metabolically unfavourable lipodystrophy-like fat distribution (e.g. IRS1) are associated with lower birthweight but those implicated in obesity or liver lipid metabolism are not. Consistent with this, recent evidence shows that fetal carriage of variants associated with adult adiposity and a favourable metabolic profile (including higher insulin sensitivity) [63] is associated with higher birthweight [64]. This could mean that a genetic predisposition to lower insulin sensitivity results in a lower birthweight but, in keeping with the monogenic and epidemiological data, the different pathways affecting insulin action are not consistently shared between birthweight and type 2 diabetes risk (Fig. 3).

\section{Quantifying the relationship between lower birthweight and type 2 diabetes that can be attributed to genetic risk}

While there is now clear support for the fetal insulin hypothesis, the question remains as to how much of the association between lower birthweight and type 2 diabetes is explained by the genetic associations. Most variants in the type 2 diabetes risk loci do not appear to be associated with birthweight and the finding that a fetal genetic score for birthweight predominantly influences pathways independent of fetal insulin secretion [65] suggests that a substantial proportion of the fetal genetic variability underlying birthweight does not overlap with underlying susceptibility to type 2 diabetes. However, it remains uncertain how much of the relationship (the covariance) between lower birthweight and type 2 diabetes could be explained by the genetic factors that do overlap. To date, using genome-wide data, shared genetic effects of common variants have been estimated to explain $36 \%$ (15-57\%) of the negative covariance between birthweight and type 2 diabetes risk [59], although this comes with the important caveat of uncertainty introduced by the likely non-linear relationship between the two phenotypes [57].

\section{Mendelian randomisation studies exploring the role of the intrauterine environment in determining relationships between lower birthweight and adult cardiometabolic disease}

While there is accumulating evidence for the relationship between lower birthweight and type 2 diabetes having a shared genetic aetiology, long-lasting effects of the intrauterine environment on early development are thought to play an important role. Many studies of animal models have shown this to be the case [66] and the most convincing evidence in humans has come from studies of offspring born during periods of famine, showing that they are at a higher risk of disorders of glucose metabolism and type 2 diabetes in adulthood (reviewed in detail in [67]). In addition, monozygotic twins discordant for type 2 diabetes have a lower birthweight [68], a finding which supports an effect of the intrauterine environment on both restricted fetal growth and developmental programming of metabolism.

Genetics can be used to test whether there is a causal relationship between an intrauterine exposure and adult type 2 diabetes by analysing genetic variants specifically associated with the exposure in a technique called Mendelian randomisation [69]. It is akin to a randomised control trial, since genetic variants are randomly assigned at birth and as the genes are specific to the exposure it is not generally subject to confounding from other factors that may mediate the relationship between the exposure and outcome. 
Fig. 3 The effect of fetal type 2 diabetes (T2D) risk alleles on birthweight (BW) clustered by their likely underlying biology (beta cell function, proinsulin secretion and insulin resistance secondary to obesity,

lipodystrophy-like fat distribution or disrupted liver lipid metabolism) [81]. SNPs within each cluster are ordered from top to bottom by highest to lowest T2D risk (established from a genome-wide association study of participants of European ancestry [61]). SNPs that appear in more than one cluster (ADCY5, CCND2, CDC123/CAMK1D, $H S D 17 B 12, H N F 4 A$ ) are shown by an accompanying number in parentheses. There are two distinct signals at ANKRD55 (shown as ANKRD55_1 and ANKRD55_2). The error bars show the $\overline{95} \%$ CIs for the estimated fetal effect on birthweight in Europeans (independent of any maternal effect [59]), with 1 SD change in birthweight being equivalent to $\sim 450 \mathrm{~g}$. This figure is available as part of a downloadable slideset

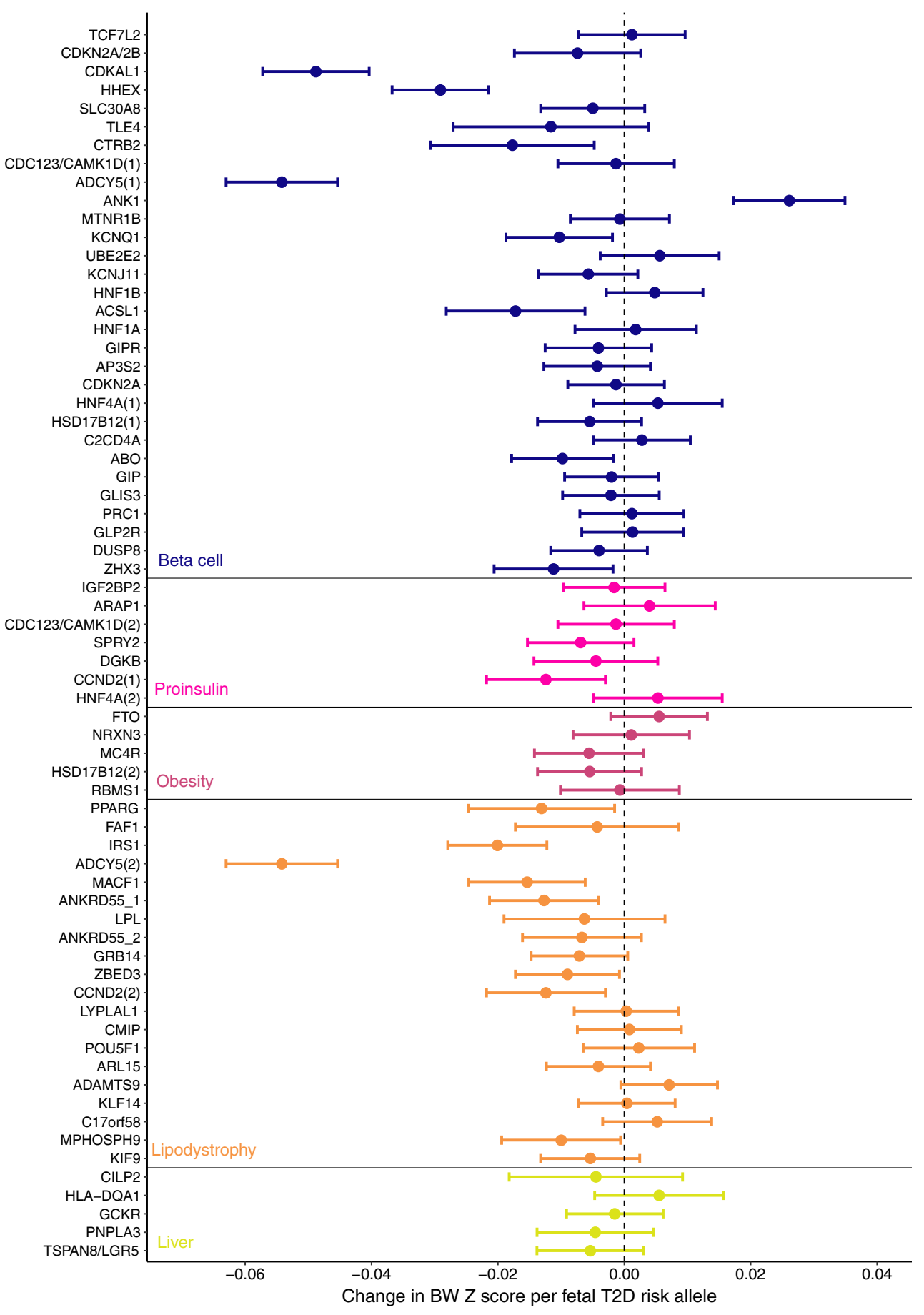

There have been attempts to use Mendelian randomisation to show that lower birthweight is causally related to type 2 diabetes [70-72] but the results were difficult to interpret as they did not appropriately differentiate between maternal and fetal effects [73-75]. Methods have been established to account for maternal and fetal effects and test for causal associations between pregnancy exposures and offspring traits $[59,60,76]$. A recent, large study of genotyped parentoffspring pairs $(n=45,849)$ showed no evidence for a causal relationship between maternal intrauterine exposures that influence birthweight and offspring quantitative cardiometabolic traits (glucose, lipids, BP, BMI) [76]. A specific example tested by Mendelian randomisation and relevant to the fetal insulin hypothesis is the relationship between maternal systolic BP (SBP) and offspring birthweight and SBP. This showed that while high maternal SBP results in reduced fetal growth, it is not causal for high offspring SBP but instead reflects a shared genetic predisposition to higher SBP (Fig. 4) [59, 76]. 
Fig. 4 Principles of using Mendelian randomisation to explore the roles of pregnancy exposures and fetal genetics in the relationship between birthweight and risk of adult cardiometabolic disease. The example in this figure shows that the relationship between lower birthweight and higher offspring SBP is mediated by a combination of intrauterine effects on birthweight and fetal genetic susceptibility to higher adult SBP. Figure adapted from Lawlor et al [75] under the terms of the Creative Commons Attribution 4.0 International License (http://creativecommons. org/licenses/by/4.0/), which permits unrestricted use, distribution, and reproduction in any medium. This figure is

available as part of a

downloadable slideset

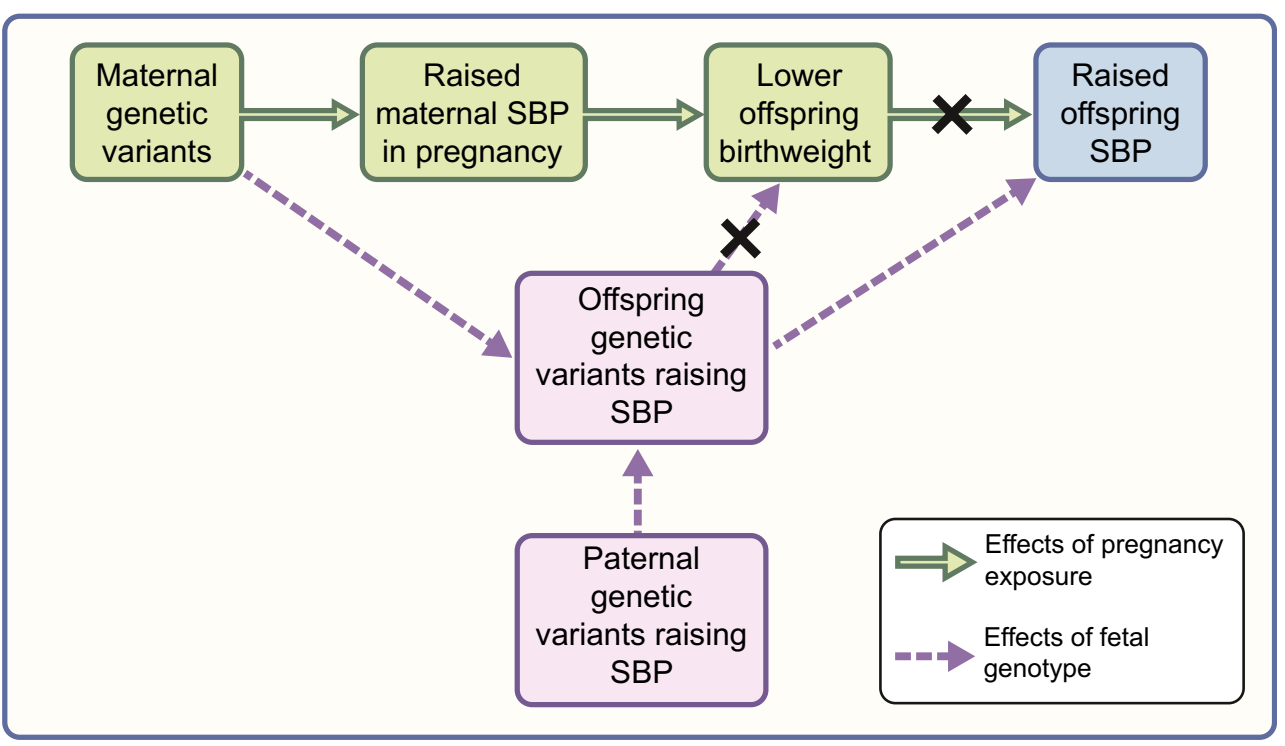

This example demonstrates a key underlying premise of the fetal insulin hypothesis: that the fetal genotype can explain observational relationships between lower birthweight and adult traits. However, unlike the fetal insulin hypothesis, the relationship between lower birthweight and higher adult SBP may be explained by a combination of maternal intrauterine effects on birthweight and fetal genetic susceptibility to higher adult SBP.

\section{Conclusion}

In the two decades since the fetal insulin hypothesis was first proposed, advances in genetic research have shed light on what contributes to fetal insulin-mediated growth and its implications for long-term risk of type 2 diabetes. Strong evidence from monogenic studies has been supported by epidemiological observations and discoveries arising from large-scale GWAS of type 2 diabetes and birthweight. Taken as a whole, it is clear that both lower birthweight and type 2 diabetes reflect, in part, a shared genetic predisposition to reduced insulin secretion. However, while impaired insulin action was considered a key part of the original fetal insulin hypothesis, studies of birthweight relating to monogenic lipodystrophies, paternal insulin resistance and the biology underlying shared birthweight and type 2 diabetes risk loci suggest this may be a less important factor in mediating the relationship between lower birthweight and type 2 diabetes risk.

Research investigating the premise of the fetal insulin hypothesis will continue to be important as type 2 diabetes becomes more prevalent globally. As this is predominantly associated with rising levels of obesity, it is possible that the variance in adult type 2 diabetes risk that can be explained by genes which also reduce insulin-mediated fetal growth becomes less important. This is because risk variants associated with high BMI are not strongly represented in birthweight GWAS and mothers with higher BMIs are at risk for diabetes in pregnancy, which leads to higher birthweights. Addressing this and other important challenges, including diversifying research to include nonEuropean populations and exploring non-linear relationships and gene-environment interactions, will provide further insights into the genetics of insulin-mediated fetal growth and its implications for health and disease across the life course.

Supplementary Information The online version of this article (https://doi. org/10.1007/s00125-021-05386-7) contains a slideset of the figures for download, which is available to authorised users.

Acknowledgements We thank J. Locke and K. Patel (both Institute of Biomedical and Clinical Science, University of Exeter Medical School, UK) for their permission to cite their unpublished data in this review.

Data availability This review did not generate any new data.

Funding AEH is supported by the Wellcome Trust and University of Exeter through a GW4 Clinical Academic Training PhD Fellowship. ATH is supported by the Wellcome Trust through a Senior Investigator Award (Grant Number WT098395/Z/12/Z) and is a National Institute of Health Research (NIHR) Senior Investigator. SEF and RMF have Sir Henry Dale Fellowships jointly funded by the Wellcome Trust and the Royal Society (Grant Numbers 104150/Z/14/Z and 105636/Z/14/Z).

Authors' relationships and activities The authors declare that there are no relationships or activities that might bias, or be perceived to bias, their work. 
Contribution statement All authors were responsible for drafting the review and revising it critically for important intellectual content. All authors approved submission. RMF is the guarantor of this work and accepts full responsibility for its content and controlled decision to publish.

Open Access This article is licensed under a Creative Commons Attribution 4.0 International License, which permits use, sharing, adaptation, distribution and reproduction in any medium or format, as long as you give appropriate credit to the original author(s) and the source, provide a link to the Creative Commons licence, and indicate if changes were made. The images or other third party material in this article are included in the article's Creative Commons licence, unless indicated otherwise in a credit line to the material. If material is not included in the article's Creative Commons licence and your intended use is not permitted by statutory regulation or exceeds the permitted use, you will need to obtain permission directly from the copyright holder. To view a copy of this licence, visit http://creativecommons.org/licenses/by/4.0/.

\section{References}

1. Barker DJP, Hales CN, Fall CHD, Osmond C, Phipps K, Clark PMS (1993) Type 2 (non-insulin-dependent) diabetes mellitus, hypertension and hyperlipidaemia (syndrome $\mathrm{X}$ ): relation to reduced fetal growth. Diabetologia 36(1):62-67. https://doi.org/ 10.1007/BF00399095

2. Hales CN, Barker DJ, Clark PM et al (1991) Fetal and infant growth and impaired glucose tolerance at age 64. BMJ 303(6809):10191022

3. Harder T, Rodekamp E, Schellong K, Dudenhausen JW, Plagemann A (2007) Birth weight and subsequent risk of type 2 diabetes: a meta-analysis. Am J Epidemiol 165(8):849-857. https:// doi.org/10.1093/aje/kwk071

4. Hales CN, Barker DJP (2001) The thrifty phenotype hypothesis. Br Med Bull 60(1):5-20. https://doi.org/10.1093/bmb/60.1.5

5. Gluckman PD, Hanson MA (2004) Living with the past: evolution, development, and patterns of disease. Science 305(5691):17331736. https://doi.org/10.1126/science.1095292

6. Hattersley AT, Beards F, Ballantyne E, Appleton M, Harvey R, Ellard S (1998) Mutations in the glucokinase gene of the fetus result in reduced birth weight. Nat Genet 19(3):268-270. https://doi.org/ $10.1038 / 953$

7. Hattersley AT, Tooke JE (1999) The fetal insulin hypothesis: an alternative explanation of the association of low birthweight with diabetes and vascular disease. Lancet 353(9166):1789-1792. https://doi.org/10.1016/S0140-6736(98)07546-1

8. Pedersen J (1952) Diabetes and pregnancy: blood sugar of newborn infants during fasting and glucose administration. Danish Science Press, Copenhagen, pp 230 (Ph. D. thesis)

9. Fernandez-Twinn DS, Hjort L, Novakovic B, Ozanne SE, Saffery $\mathrm{R}$ (2019) Intrauterine programming of obesity and type 2 diabetes. Diabetologia 62(10):1789-1801. https://doi.org/10.1007/s00125019-4951-9

10. Stride A, Vaxillaire M, Tuomi T et al (2002) The genetic abnormality in the beta cell determines the response to an oral glucose load. Diabetologia 45(3):427-435. https://doi.org/10.1007/s00125001-0770-9

11. Steele AM, Wensley KJ, Ellard S et al (2013) Use of HbA1c in the Identification of Patients with Hyperglycaemia Caused by a Glucokinase Mutation: Observational Case Control Studies. PLoS One 8(6). https://doi.org/10.1371/journal.pone.0065326
12. Caswell RC, Snowsill T, Houghton JAL et al (2020) Noninvasive Fetal Genotyping by Droplet Digital PCR to Identify Maternally Inherited Monogenic Diabetes Variants. Clin Chem 66(7):958965. https://doi.org/10.1093/clinchem/hvaa104

13. Gloyn AL, Pearson ER, Antcliff JF et al (2004) Activating Mutations in the Gene Encoding the ATP-Sensitive PotassiumChannel Subunit Kir6.2 and Permanent Neonatal Diabetes. N Engl J Med 350(18):1838-1849. https://doi.org/10.1056/ NEJMoa032922

14. Proks P, Arnold AL, Bruining J et al (2006) A heterozygous activating mutation in the sulphonylurea receptor SUR1 (ABCC8) causes neonatal diabetes. Hum Mol Genet 15(11):1793-1800. https://doi.org/10.1093/hmg/ddl101

15. Flanagan SE, Patch A-M, Mackay DJG et al (2007) Mutations in ATP-Sensitive K+ Channel Genes Cause Transient Neonatal Diabetes and Permanent Diabetes in Childhood or Adulthood. Diabetes 56(7):1930-1937. https://doi.org/10.2337/db07-0043

16. Slingerland AS, Hattersley AT (2006) Activating mutations in the gene encoding Kir6.2 alter fetal and postnatal growth and also cause neonatal diabetes. J Clin Endocrinol Metab 91(7):2782-2788. https://doi.org/10.1210/jc.2006-0201

17. Garin I, Edghill EL, Akerman I et al (2010) Recessive mutations in the INS gene result in neonatal diabetes through reduced insulin biosynthesis. Proc Natl Acad Sci USA 107(7):3105-3110. https:// doi.org/10.1073/pnas.0910533107

18. De Franco E, Watson RA, Weninger WJ et al (2019) A Specific CNOT1 Mutation Results in a Novel Syndrome of Pancreatic Agenesis and Holoprosencephaly through Impaired Pancreatic and Neurological Development. Am J Hum Genet 104(5):985989. https://doi.org/10.1016/j.ajhg.2019.03.018

19. Shaw-Smith C, De Franco E, Allen HL et al (2014) GATA4 Mutations Are a Cause of Neonatal and Childhood-Onset Diabetes. Diabetes 63(8):2888-2894. https://doi.org/10.2337/ db14-0061

20. Allen HL, Flanagan SE, Shaw-Smith C et al (2012) GATA6 haploinsufficiency causes pancreatic agenesis in humans. Nat Genet 44(1):20-22. https://doi.org/10.1038/ng.1035

21. Stoffers DA, Zinkin NT, Stanojevic V, Clarke WL, Habener JF (1997) Pancreatic agenesis attributable to a single nucleotide deletion in the human IPF1 gene coding sequence. Nat Genet 15(1):106-110. https://doi.org/10.1038/ng0197-106

22. Weedon MN, Cebola I, Patch A-M et al (2014) Recessive mutations in a distal PTF1A enhancer cause isolated pancreatic agenesis. Nat Genet 46(1):61-64. https://doi.org/10.1038/ng.2826

23. Houghton JAL, Swift GH, Shaw-Smith C et al (2016) Isolated Pancreatic Aplasia Due to a Hypomorphic PTF1A Mutation. Diabetes 65(9):2810-2815. https://doi.org/10.2337/db15-1666

24. De Franco E, Flanagan SE, Houghton JA et al (2015) The effect of early, comprehensive genomic testing on clinical care in neonatal diabetes: an international cohort study. Lancet 386(9997):957-963. https://doi.org/10.1016/S0140-6736(15)60098-8

25. Fowden AL, Forhead AJ (2009) Endocrine Regulation of FetoPlacental Growth. Horm Res Paediatr 72(5):257-265. https://doi. org/10.1159/000245927

26. Byrne MM, Sturis J, Fajans SS et al (1995) Altered insulin secretory responses to glucose in subjects with a mutation in the MODY1 gene on chromosome 20. Diabetes 44(6):699-704. https://doi.org/ 10.2337/diab.44.6.699

27. Byrne MM, Sturis J, Menzel S et al (1996) Altered Insulin Secretory Responses to Glucose in Diabetic and Nondiabetic Subjects With Mutations in the Diabetes Susceptibility Gene MODY3 on Chromosome 12. Diabetes 45(11):1503-1510. https://doi.org/10.2337/diab.45.11.1503

28. Pearson ER, Pruhova S, Tack CJ et al (2005) Molecular genetics and phenotypic characteristics of MODY caused by hepatocyte nuclear factor $4 \alpha$ mutations in a large European collection. 
Diabetologia 48(5):878-885. https://doi.org/10.1007/s00125-0051738-y

29. Pearson ER, Boj SF, Steele AM et al (2007) Macrosomia and Hyperinsulinaemic Hypoglycaemia in Patients with Heterozygous Mutations in the HNF4A Gene. PLoS Med 4(4):e118. https://doi. org/10.1371/journal.pmed.0040118

30. Glaser B (2007) Type 2 Diabetes: Hypoinsulinism, Hyperinsulinism, or Both? PLoS Med 4(4):e148. https://doi.org/ 10.1371/journal.pmed.0040148

31. Harries LW, Locke JM, Shields B et al (2008) The Diabetic Phenotype in HNF4A Mutation Carriers Is Moderated By the Expression of HNF4A Isoforms From the P1 Promoter During Fetal Development. Diabetes 57(6):1745-1752. https://doi.org/10. 2337/db07-1742

32. Lambert É, Babeu J-P, Simoneau J et al (2020) Human Hepatocyte Nuclear factor 4- $\alpha$ Encodes Isoforms with Distinct Transcriptional Functions. Mol Cell Proteomics 19(5):808-827. https://doi.org/10. 1074/mcp.RA119.001909

33. Donohue WL, Uchida I (1954) Leprechaunism: a euphemism for a rare familial disorder. J Pediatr 45(5):505-519. https://doi.org/10. 1016/s0022-3476(54)80113-2

34. Elsas LJ, Endo F, Strumlauf E, Elders J, Priest JH (1985) Leprechaunism: an inherited defect in a high-affinity insulin receptor. Am J Hum Genet 37(1):73-88

35. Krook A, O'Rahilly S, Brueton L (1993) Homozygous nonsense mutation in the insulin receptor gene in infant with leprechaunism. Lancet 342(8866):277-278. https://doi.org/10.1016/01406736(93)91820-C

36. Garg A, Agarwal AK (2009) Lipodystrophies: Disorders of adipose tissue biology. Biochimica Biophysica Acta Mol Cell Biol Lipids 1791(6):507-513. https://doi.org/10.1016/j.bbalip.2008.12.014

37. Seip M, Trygstad O (1996) Generalized lipodystrophy, congenital and acquired (lipoatrophy). Acta Paediatrica 85(s413):2-28. https:// doi.org/10.1111/j.1651-2227.1996.tb14262.x

38. Muschke P, Kölsch U, Jakubiczka S, Wieland I, Brune T, Wieacker P (2007) The heterozygous LMNA mutation p.R471G causes a variable phenotype with features of two types of familial partial lipodystrophy. Am J Med Genet A 143A(23):2810-2814. https:// doi.org/10.1002/ajmg.a.32046

39. Krawiec P, Mełges B, Pac-Kożuchowska E, MroczkowskaJuchkiewicz A, Czerska K (2016) Fitting the pieces of the puzzle together: a case report of the Dunnigan-type of familial partial lipodystrophy in the adolescent girl. BMC Pediatr 16(1):38. https://doi.org/10.1186/s12887-016-0581-2

40. Shackleton S, Lloyd DJ, Jackson SN et al (2000) LMNA, encoding lamin A/C, is mutated in partial lipodystrophy. Nat Genet 24(2): 153-156. https://doi.org/10.1038/72807

41. Barroso I, Gurnell M, Crowley VE et al (1999) Dominant negative mutations in human PPARgamma associated with severe insulin resistance, diabetes mellitus and hypertension. Nature 402(6764): 880-883. https://doi.org/10.1038/47254

42. Gandotra S, Le Dour C, Bottomley W et al (2011) Perilipin Deficiency and Autosomal Dominant Partial Lipodystrophy. N Engl J Med 354(8):740-748. https://doi.org/10.1056/ NEJMoa1007487

43. Tyrrell JS, Yaghootkar H, Freathy RM, Hattersley AT, Frayling TM (2013) Parental diabetes and birthweight in 236030 individuals in the UK Biobank Study. Int J Epidemiol 42(6):1714-1723. https://doi.org/10.1093/ije/dyt220

44. Lindsay RS, Dabelea D, Roumain J, Hanson RL, Bennett PH, Knowler WC (2000) Type 2 diabetes and low birth weight: the role of paternal inheritance in the association of low birth weight and diabetes. Diabetes 49(3):445-449. https://doi.org/10.2337/diabetes. 49.3.445
45. HAPO Study Cooperative Research Group (2008) Hyperglycemia and adverse pregnancy outcomes. N Engl J Med 358(19):19912002. https://doi.org/10.1056/NEJMoa0707943

46. Hillman S, Peebles DM, Williams DJ (2013) Paternal metabolic and cardiovascular risk factors for fetal growth restriction: a casecontrol study. Diabetes Care 36(6):1675-1680. https://doi.org/10. 2337/dc12-1280

47. Wannamethee SG, Lawlor DA, Whincup PH, Walker M, Ebrahim S, Davey-Smith G (2004) Birthweight of offspring and paternal insulin resistance and paternal diabetes in late adulthood: cross sectional survey. Diabetologia 47(1):12-18. https://doi.org/10. 1007/s00125-003-1270-x

48. Knight B, Shields BM, Hill A et al (2006) Offspring birthweight is not associated with paternal insulin resistance. Diabetologia 49(11): 2675-2678. https://doi.org/10.1007/s00125-006-0417-y

49. Shields BM, Knight B, Turner M et al (2006) Paternal insulin resistance and its association with umbilical cord insulin concentrations. Diabetologia 49(11):2668-2674. https://doi.org/10.1007/s00125006-0282-8

50. Sladek R, Rocheleau G, Rung J et al (2007) A genome-wide association study identifies novel risk loci for type 2 diabetes. Nature 445(7130):881-885. https://doi.org/10.1038/nature05616

51. Zeggini E, Weedon MN, Lindgren CM et al (2007) Replication of genome-wide association signals in UK samples reveals risk loci for type 2 diabetes. Science 316(5829):1336-1341. https://doi.org/ 10.1126/science. 1142364

52. Zeggini E, Scott LJ, Saxena R et al (2008) Meta-analysis of genome-wide association data and large-scale replication identifies additional susceptibility loci for type 2 diabetes. Nat Genet 40(5): 638-645. https://doi.org/10.1038/ng.120

53. Freathy RM, Bennett AJ, Ring SM et al (2009) Type 2 diabetes risk alleles are associated with reduced size at birth. Diabetes 58(6): 1428-1433. https://doi.org/10.2337/db08-1739

54. Zhao J, Li M, Bradfield JP et al (2009) Examination of type 2 diabetes loci implicates CDKAL1 as a birth weight gene. Diabetes 58(10):2414-2418. https://doi.org/10.2337/db09-0506

55. Freathy RM, Mook-Kanamori DO, Sovio U et al (2010) Variants in ADCY 5 and near CCNL1 are associated with fetal growth and birth weight. Nat Genet 42(5):430-435. https://doi.org/10.1038/ng.567

56. Hodson DJ, Mitchell RK, Marselli L et al (2014) ADCY5 Couples Glucose to Insulin Secretion in Human Islets. Diabetes 63(9):30093021. https://doi.org/10.2337/db13-1607

57. Horikoshi M, Beaumont RN, Day FR et al (2016) Genome-wide associations for birth weight and correlations with adult disease. Nature 538(7624):248-252. https://doi.org/10.1038/nature19806

58. Beaumont RN, Warrington NM, Cavadino A et al (2018) Genomewide association study of offspring birth weight in 86577 women identifies five novel loci and highlights maternal genetic effects that are independent of fetal genetics. Hum Mol Genet 27(4):742-756. https://doi.org/10.1093/hmg/ddx429

59. Warrington NM, Beaumont RN, Horikoshi M et al (2019) Maternal and fetal genetic effects on birth weight and their relevance to cardio-metabolic risk factors. Nat Genet 51(5):804-814. https:// doi.org/10.1038/s41588-019-0403-1

60. Warrington NM, Freathy RM, Neale MC, Evans DM (2018) Using structural equation modelling to jointly estimate maternal and fetal effects on birthweight in the UK Biobank. Int J Epidemiol 47(4): 1229-1241. https://doi.org/10.1093/ije/dyy015

61. Mahajan A, Taliun D, Thurner M et al (2018) Fine-mapping type 2 diabetes loci to single-variant resolution using high-density imputation and islet-specific epigenome maps. Nat Genet 50(11):15051513. https://doi.org/10.1038/s41588-018-0241-6

62. Lizio M, Ishizu Y, Itoh M et al (2015) Mapping Mammalian Celltype-specific Transcriptional Regulatory Networks Using KDCAGE and ChIP-seq Data in the TC-YIK Cell Line. Front Genet 6:331. https://doi.org/10.3389/fgene.2015.00331 
63. Yaghootkar H, Lotta LA, Tyrrell J et al (2016) Genetic Evidence for a Link Between Favorable Adiposity and Lower Risk of Type 2 Diabetes, Hypertension, and Heart Disease. Diabetes 65(8):24482460. https://doi.org/10.2337/db15-1671

64. Thompson WD, Beaumont RN, Kuang A et al (2020) Fetal alleles predisposing to metabolically favourable adiposity are associated with higher birth weight. bioRxiv 302208 (Preprint). 17 Sep 2020. Available from: https://doi.org/10.1101/2020.09.17.302208

65. Hughes AE, Nodzenski M, Beaumont RN et al (2018) Fetal Genotype and Maternal Glucose Have Independent and Additive Effects on Birth Weight. Diabetes 67(5):1024-1029. https://doi. org/10.2337/db17-1188

66. Bertram CE, Hanson MA (2001) Animal models and programming of the metabolic syndrome: Type 2 diabetes. Br Med Bull 60(1): 103-121. https://doi.org/10.1093/bmb/60.1.103

67. Stein AD, Obrutu OE, Behere RV, Yajnik CS (2019) Developmental undernutrition, offspring obesity and type 2 diabetes. Diabetologia 62(10):1773-1778. https://doi.org/10.1007/ s00125-019-4930-1

68. Poulsen P, Vaag AA, Kyvik KO, Møller Jensen D, Beck-Nielsen H (1997) Low birth weight is associated with NIDDM in discordant monozygotic and dizygotic twin pairs. Diabetologia 40(4):439446. https://doi.org/10.1007/s001250050698

69. Lawlor DA, Harbord RM, Sterne JAC, Timpson N, Smith GD (2008) Mendelian randomization: Using genes as instruments for making causal inferences in epidemiology. Stat Med 27(8):11331163. https://doi.org/10.1002/sim.3034

70. Wang T, Huang T, Li Y et al (2016) Low birthweight and risk of type 2 diabetes: a Mendelian randomisation study. Diabetologia 59(9):1920-1927. https://doi.org/10.1007/s00125-016-4019-z

71. Zanetti D, Tikkanen E, Gustafsson S, Priest JR, Burgess S, Ingelsson E (2018) Birthweight, Type 2 Diabetes Mellitus, and Cardiovascular Disease. Circ Genom Precisi Med 11(6):e002054. https://doi.org/10.1161/CIRCGEN.117.002054

72. Huang T, Wang T, Zheng Y et al (2019) Association of Birth Weight With Type 2 Diabetes and Glycemic Traits: A Mendelian Randomization Study. JAMA Netw Open 2(9):e1910915e1910915. https://doi.org/10.1001/jamanetworkopen.2019.10915

73. Freathy RM (2016) Can genetic evidence help us to understand the fetal origins of type 2 diabetes? Diabetologia 59(9):1850-1854. https://doi.org/10.1007/s00125-016-4057-6

74. Cousminer DL, Freathy RM Genetics of early growth traits. Hum Mol Genet 29(R1):R66-R72. https://doi.org/10.1093/hmg/ ddaa149
75. Lawlor D, Richmond R, Warrington $\mathrm{N}$ et al (2017) Using Mendelian randomization to determine causal effects of maternal pregnancy (intrauterine) exposures on offspring outcomes: Sources of bias and methods for assessing them. Wellcome Open Res 2:11. https://doi.org/10.12688/wellcomeopenres.10567.1

76. Moen G-H, Brumpton B, Willer C et al (2020) Mendelian randomization study of maternal influences on birthweight and future cardiometabolic risk in the HUNT cohort. Nat Commun 11(1): 5404. https://doi.org/10.1038/s41467-020-19257-z

77. Edghill EL, Bingham C, Slingerland AS et al (2006) Hepatocyte nuclear factor-1 beta mutations cause neonatal diabetes and intrauterine growth retardation: support for a critical role of HNF-1 $\beta$ in human pancreatic development. Diabet Med 23(12):1301-1306. https://doi.org/10.1111/j.1464-5491.2006.01999.x

78. Agarwal AK, Arioglu E, de Almeida $\mathrm{S}$ et al (2002) AGPAT2 is mutated in congenital generalized lipodystrophy linked to chromosome 9q34. Nat Genet 31(1):21-23. https://doi.org/10.1038/ng880

79. Magré J, Delépine M, Khallouf E et al (2001) Identification of the gene altered in Berardinelli-Seip congenital lipodystrophy on chromosome 11q13. Nat Genet 28(4):365-370. https://doi.org/10.1038/ ng585

80. Kim CA, Delépine M, Boutet E et al (2008) Association of a Homozygous Nonsense Caveolin-1 Mutation with BerardinelliSeip Congenital Lipodystrophy. J Clin Endocrinol Metab 93(4): 1129-1134. https://doi.org/10.1210/jc.2007-1328

81. Udler MS, Kim J, von Grotthuss M et al (2018) Type 2 diabetes genetic loci informed by multi-trait associations point to disease mechanisms and subtypes: A soft clustering analysis. PLoS Medicine 15(9):e1002654. https://doi.org/10.1371/journal.pmed. 1002654

82. Mahajan A, Wessel J, Willems SM et al (2018) Refining the accuracy of validated target identification through coding variant finemapping in type 2 diabetes. Nat Genet 50(4):559-571. https://doi. org/10.1038/s41588-018-0084-1

83. Thomsen SK, Ceroni A, van de Bunt M et al (2016) Systematic Functional Characterization of Candidate Causal Genes for Type 2 Diabetes Risk Variants. Diabetes 65(12):3805-3811. https://doi. org/10.2337/db16-0361

Publisher's note Springer Nature remains neutral with regard to jurisdictional claims in published maps and institutional affiliations. 